\title{
SOCIAL ENTREPRENEURSHIP AVENUES FOR THE FIELD DEVELOPMENT THROUGH RESEARCH PARADIGM INTERSECTION DISCUSSION ${ }^{2}$
}

\begin{abstract}
The aim of this paper is to identify and provide key antecedents that can serve arguments for employing integrative approach in the choice of research paradigm in Burrell and Morgan's paradigm typology, for describing, exploring and explaining social entrepreneurship phenomenon. The author suggests that the proposed research paradigms are not mutually exclusive. The fact that social entrepreneurship as a field of research is at its preliminary stage, serves as an argument and gives freedom in the discussion of the choice of employing a research paradigm. The author does so through identifying commonalities and converging points that allow for employment different research paradigms in social entrepreneurship as a subfield of entrepreneurship research. In the first part of the paper the reader is introduced into the concept of social entrepreneurship and introduce the development of this field. Subsequently, societal dimension of the social entrepreneurship is highlighted, with emphasis placed on the importance of intangible elements of the process, cauldron of social interactions involved, contextuality and processual nature of this phenomenon. This is followed by the overview the key research paradigms and discussion on a research potential of all four approaches in pushing the boundaries of this area - subfield further.
\end{abstract}

Keywords: Social entrepreneurship, social enterprise, methodology, research paradigm, institutional theory.

\section{INTRODUCTION}

This paper is an effort to identify key arguments, important in the discussion on the research paradigm dimension of social entrepreneurship research. For scholars, social entrepreneurship research has been positioned at pre-paradigmatic stage ${ }^{3}$, focusing mainly of definitional issues and debates ${ }^{4}$. Also there is a plethora of anecdotal evidence, very often based on the ideal (high profile) examples of social enterprises and social

${ }^{1} \mathrm{PhD}$, Faculty of Management and Economics, Gdansk University of Technology, 11/12 Narutowicza St., 80-233 Gdansk, mstarnaw@zie.pg.gda.pl, 583486290

2 The project has been partly financed from National Science Centre funds based on the decision No. DEC-2011/03/D/HS4/04326.

3 A. Nicholls, The Legitimacy of Social Entrepreneurship: Reflexive Isomorphism in a PreParadigmatic Field, "Entrepreneurship Theory and Practice" 34/4, (2010), pp. 611-633

${ }^{4}$ M. Starnawska, Social entrepreneurship research - challenges, explanations and suggestions for the field development, "Problemy Zarządzania" 3/61, (2016), pp. 13-31; T. Piecuch, Charakterystyka przedsiębiorców społecznych - przegląd literatury, „Ekonomia Społeczna” 2, (2014), p. 58-68. 
entrepreneurs ${ }^{5}$. Lack of conceptual clarity and widely acknowledged definitions, does not allow the development of shared conceptual framework. Lack of established theoretical framework, necessitates the inductive research approach, and indeed the dominant research has evolved around single, or multiple case studies with a very few large quantitative, based on large samples deductively oriented approaches ${ }^{6}$.

If we consider social entrepreneurship field as a part of entrepreneurship field with its constituent ontologies, epistemologies, methodologies and associated research paradigms, the boundaries on existing knowledge can be pushed or extended, through using existing theoretical framework in entrepreneurship research. However, some arguments are made, that social entrepreneurship is a field of practice and research is a separate domain, as there is dichotomy between economy and society, employing market logics and at the same time employing non-market logic. Therefore there are, inherent tensions hidden between social and economic aims, means to achieve them and outcomes or impact generated by social entrepreneurship. More often, research employs a notion of social enterprise as hybrid ${ }^{7}$ and emphasizes related conflicts and tensions and paradoxes resulting in debate on where and how social entrepreneurship can be researched.

The preliminary stage of social entrepreneurship research generates a potential for valuable discussion on the positioning of this field in widely acknowledged paradigm classification proposed by Burrell and $\operatorname{Morgan}^{8}$ functionalist, interpretivist, radical structuralist and radical humanist. In this paper the aim is to provide an overview arguments, that research on social entrepreneurship does not need to be exclusively situated in any of the four research paradigms, which so far have been treated as inconsumerable, but rather make efforts to cross them.

\section{SOCI(ET)AL ENTREPRENEURSHIP -POINTS FOR REVISING THE CONCEPT AND PHENOMENON FOR PARADIGM DISCUSSION}

Despite ongoing definitional debates on the concept and phenomenon of social entrepreneurship, there have been three dominant schools in social entrepreneurship research: social innovation, earned income, and EMES, which emerged in more than

\footnotetext{
${ }^{5}$ E.S. O'Connor, Location and relocation, visions and revisions: opportunities for social entrepreneurship, [in:] Entrepreneurship as Social Change, eds. C. Steyaert, D. Hjorth, Edward Elgar, Cheltenham UK and Northampton MA USA 2006, pp. 79-96.

${ }^{6}$ See more: M. Lee, J. Battilana, T. Wang, Building and infrastructure for empirical research on social enterprise: challenges and opportunities, [in:] Social Entrepreneurship and Research Methods, ed. J. Short, Emerald Group Publishing Limited, Published Online 2014, pp. 241-264.

${ }^{7}$ B. Doherty, H. Haugh, F. Lyon, Social enterprises as hybrid organizations: a review and research agenda, "International Journal of Management Reviews" 16, (2014), pp. 417-436.

${ }^{8}$ G. Burrell, G. Morgan, Sociological paradigms and Organizational Analysis, Heinemann, London 1979.
} 
a two decades now 9 . What all approaches have in common is, the social aim in social entrepreneurship, as an undiscussable feature ${ }^{10}$.

In this paper, we approach social entrepreneurship sensu largo, in a broad nature, as entangling societal rather than solely social aim focus and dimension. We follow the approach of Swedberg, who reviewed early works by Schumpeter ${ }^{11}$. Contrary to what entrepreneurship research claimed about Schumpeter's view on entrepreneurship contribution to the economic change, Swedberg has emphasized that Schumpeter originally highlighted the contribution of entrepreneurship to both economic and noneconomic areas of society. Therefore, we find it important, that the subject of social entrepreneurship research incorporates social meaning societal aspects of entrepreneurial activity as well as entrepreneurial aspects of soci(et)al action ${ }^{12}$. These assumptions are important for the discussion of paradigm choices, which are explained in ensuing sections of this paper. Therefore, the concept of social entrepreneurship has been slowly recognized as not solely focusing on the social aim achievement in a narrow sense (as solving social problems, or more narrowly - social policy related) as a unifying concept. More, the discussion on the scope of social aims and problems can also be extended beyond Millennium or Sustainable Development Goals. It has become recognized as societal entrepreneurship, as it may involve social ownership, interactions and relationship involvement with environment - surrounding organizations and actors (in management named as stakeholders), in effect bringing both economic and social impact ${ }^{13}$. Therefore, social entrepreneurship is even more, when compared with conventional entrepreneurship, embedded in the environment, with social aims defined around social problems and opportunities arising from communities, generating value in complex fabric of social interactions and relations that are enacted and negotiated in the process. Kaufman ${ }^{14}$ uses a concept of bubbling cauldron of organizational soup - to refer to entrepreneurial activity. This action refers to place understood as social spheres (not only geographically

9 J. Defourny, M. Nyssens, The EMES approach of social enterprise in a comparative perspective, "Working Paper" no. 12/03, (2013), EMES European Research Network; A. Ciepielewska-Kowalik, B. Pieliński, M. Starnawska, A. Szymańska, Social enterprise in Poland: institutional and historical context, "ICSEM Working Papers" 11, (2015) The International Comparative Social Enterprise Models (ICSEM) Project: Liege.

${ }^{10}$ A. Nicholls, The Legitimacy..., op. cit.

${ }^{11}$ R. Swedberg, Social entrepreneurship: the view of the young Schumpeter [in:] Entrepreneurship as Social Change, eds. C. Steyaert, D. Hjorth, Edward Elgar, Cheltenham UK and Northampton MA USA 2006, pp. 21-34.

${ }^{12}$ E.S. O'Connor, Location and relocation..., op. cit.

${ }^{13}$ These dimensions are very often overlooked in the research on social enterprise organizations. These are usually located in social economy, that is approach as area for social and economic integration of marginalized groups, therefore serving for the purpose of fighting and preventing social and economic marginalization of the disadvantaged members of the society. Whereas the dimension of embeddedness, rebuilding links with local community and strengthening the roots is also a key element of social economy, and this latter dimension is often overlooked in research and practice of social entrepreneurship. This is exemplified in the Polish Parliament proposal on Act on Social Enterprise. See more: Poselski projekt ustawy o przedsiębiorstwie społecznym $i$ wspieraniu podmiotów ekonomii społecznej. 2015. http://orka.sejm.gov.pl/Druki7ka.nsf/0/ B349885CF7ED5077C1257E690042C6D9/\%24File/3521-ustawa.docx.

${ }^{14}$ H. Kaufman, Time, Chance, and Organizations, Chatham House, Chatham, NJ 1985. 
delimited) and process - involving interactions, interdependencies ${ }^{15}$. Entrepreneurial process means not only economic but also social, intangible assets, of social, personal and even emotional dimension, employing social networks, social capital and trust. It is likely, that members of local community, local leaders, involved in social movements and activities, at a certain point of social change, establish more or less formal groups and organizations, often establishing themselves in the Third Sector, to finally operate as social enterprise. Social entrepreneurship as societal process also involves legitimacy building with different actors. Legitimacy is built in the communities, among different actors, as a supplementary asset for resource acquisition among social enterprises. This also shows, that social entrepreneurship as a phenomenon, and indeed as a process, is continually constructed, via interaction between entrepreneurs - different social actors and their environments ${ }^{16}$. Following this line of thinking and discussion in entrepreneurship research, Anderson and Diochon ${ }^{17}$ argue that to better learn about social entrepreneurship the focus should move away from "who a social entrepreneur is"18 to "how social entrepreneurship occurs". This naturally generates a process approach to (social) entrepreneurship research. Following these points on the crucial role of social context for social entrepreneurship, we are more inclined to research social entrepreneurship, through individual experience, idiographic description and recognition of the worlds constructed by individuals, therefore more subjective approach is desired here.

Also, through the recognition of the social aim as distinguishing feature of social entrepreneurship, organizations and individuals involved display not necessarily regulative approach to reality but one moving towards continuous conflict and struggles for empowerment, freedom. In this vein, it is argued that paradigm classifications regulative or radical change are limiting, not broadening, research potential hidden in the field of social entrepreneurship. Social entrepreneurship research has been welcomed by scientific community from different disciplines such as: sociology, political sciences, management and public management, ethics, and entrepreneurship but, as Othmar and Kansinkas ${ }^{19}$ point, this does not result in a diversity of meta-theories. In fact, it is clear that research from disciplines other than entrepreneurship or management like sociology, political sciences, ethics is likely to be seen in paradigm split, based on the question of society as aiming for order or conflict. However, we propose, that recognition of more radical approach, can serve as a broadening antecedent to understand social entrepreneurship phenomenon. Here, social movements become organizations and social

15 E.S.O'Connor, Location and relocation..., op. cit.

16 A.R. Anderson, S.D. Dodd, S.L. Jack, Network practices and entrepreneurial growth, "Scandinavian Journal of Management" 26/2, (2010), pp. 121-133.

17 M. Diochon, G. Durepos, A.R. Anderson, Understanding Opportunity in Social Entrepreneurship as Paradigm Interplay [in:] Social and Sustainable Entrepreneurship. Advances in Entrepreneurship, Firm Emergence and Growth 13, eds. G.T. Lumpkin, J.A. Katz, Emerald Group Publishing Limited, Published Online 2011, pp. 73-110.

18 There is still a strong focus on the "who", for overview of this approach see more: T. Piecuch, Charakterystyka przedsiębiorców społecznych - przegląd literatury, „Ekonomia Społeczna” 2 , (2014), p. 58-68

19 O.M. Lehner, J. Kansikas, Social Entrepreneurship Research across Disciplines: Paradigmatic and Methodological Considerations, 3rd EMES Research Conference, Social Innovation through Social Entrepreneurship in Civil Society 4-7 July 2011, Roskilde University, Denmark 
enterprise organizations, also minority problems and rights become more widely discussed issues in the public agenda and receive more recognition. Radical change stance opens our eyes to definition of a social problem, which in many academic ad practitioner circles is limited to social and work integration of marginalized groups ${ }^{20}$.

\section{PARADIGM OVERVIEW}

In social sciences, Burrell and Morgan ${ }^{21}$ proposed a widely used and acknowledged classification of research paradigms. They have employed two criteria for distinguishing four types of paradigms. One criterion is based on the nature of reality and ontological and epistemological assumptions around how this reality should be researched. The following two approaches - objectivism and subjectivism in what reality means creates two paradigms -functionalist and interpretivist. In case of former, the reality is independent and objective, a set of tools and instruments can be used to identify universal rules about this reality, employing statistical methods based on large amounts of quantitative data. In case of latter, there is an emphasis placed on individual experiences, therefore to learn about the reality one needs to get as close as possible to an individual and learn about their experiences, worlds, which are unique, as a result qualitative approach to research is used here. Another criterion considers the nature of society and its order. They summarize and introduce two sociological approaches: sociology of regulation - claiming that society aims towards order, whereas the other paradigm assumes the pursuit for radical change, where individuals, groups, societies struggle in constant conflict because of differences, divisions and power struggles.

Table 1. Social science research paradigms by Burrell and Morgan

\begin{tabular}{|c|c|c|c|}
\hline & Radic & hange & \\
\hline \multirow[t]{2}{*}{ Subjectivism } & $\begin{array}{l}\text { RADICAL } \\
\text { HUMANIST }\end{array}$ & $\begin{array}{c}\text { RADICAL } \\
\text { STRUCTURALIST }\end{array}$ & \multirow[t]{2}{*}{ Objectivism } \\
\hline & INTERPRETIVIST & FUNCTIONALIST & \\
\hline & \multicolumn{2}{|c|}{ Regulation } & \\
\hline
\end{tabular}

Source: G. Burrell, G. Morgan, Sociological paradigms and Organizational Analysis, Heinemann, London 1979.

In following paragraphs, based on the work by Burrell and Morgan ${ }^{22}$ we briefly summarize each of the paradigms to provide their core assumptions which can serve as ensuing arguments for paradigm intersection in social entrepreneurship research:

${ }^{20}$ Dominant discussion on social enterprise practice and research in Poland is based on the problems of work and social integration of marginalized groups, as defined by law, with some incorporation of activity in health or educational sector. Indeed, there is a lack of and need for, wider understanding of societal challenges, considering means and ways to enhance individual and society welfare in work and everyday life experience.

${ }^{21}$ G. Burrell, G. Morgan, Sociological paradigms and Organizational Analysis, Heinemann, London 1979.

22 Ibidem. 


\section{Functionalism}

Functionalism assumes that the reality is the social world, which is tangible, concrete and exists independent from those who research it. This approach implies that data gathered through researched is free from bias, and one can gain a clear and full understanding of a phenomenon. The social phenomenon, can be measured and identified accurately here. Functionalism supporters have been well established in management research, giving recommended best practices, building universal models, offering predictions for different phenomena. Functionalism, originally employed in life and technical sciences, uses quantitative approaches.

\section{Interpretivism}

The next paradigmatic approach displays subjective approach to the reality. The reality is the one that is constructed by individual actors. Therefore any attempts made at describing and explaining the reality are based on how individuals construct the world around them in everyday practices. Social world and social reality is intersubjectively built and meanings shared among actors.

\section{Radical structuralism}

This paradigmatic approach is based on the assumption of the objective reality but assumes a radical change perspective. Radical change is in the very nature of the world, resulting from this, followers of this paradigm are interested in the inherent power, domination, conflicts embedded in social reality. The purpose of the research is to offer solutions to support freedom of the disadvantaged groups, freedom from the dominance of other - powerful actors.

\section{Radical humanism}

Similarly to radical structuralism, this paradigm assumes radical change as the natural element of order. However, individuals and their consciousness is dominated by ideology, making them live in a false reality, not allowing them to live the real life. As a result, the purpose of research is to deconstruct these hidden traps and dominant ideologies. So that humans could free themselves and develop. The society is against the individual, and researchers in this paradigm make efforts to communicate how individuals are manipulated, dominated by the society.

\section{PARADIGM INTERPLAY}

The above paradigms are claimed to be exclusive, incommensurable, what hinders experimenting with paradigms. A large scale systematic literature review in the field by Lehner and Kansikas reveals that research in the field of social entrepreneurship has been mainly focused in functionalist and interpretivist paradigms, and there have been very few studies employing radical change perspective in any - subjective or objective approach ${ }^{23}$. There have been very scarce attempts, to explicitly combine paradigmatic approaches as done in the work by Diochon et al. ${ }^{24}$ on social entrepreneurship opportunities who combined functionalist and interpretivist lenses to opportunity in entrepreneurial process

\footnotetext{
${ }^{23}$ O.M. Lehner, J. Kansikas, Social Entrepreneurship..., op. cit.

${ }^{24}$ M. Diochon, G. Durepos, A.R. Anderson, Understanding Opportunity..., op. cit.
} 
and Nicolopoulou's ${ }^{25}$ conceptual study on transformation of Bordieu's capitals and role of paradigm interplay in social entrepreneurship research. However, a lot of work reviewed by Lehner and Kansinkas ${ }^{26}$ employ research paradigms with inconsistencies, what they explain by mixed research methods approach, responding to the complexity of social science research, employing quantitative methods with nomothetic approach and qualitative methods with ideographic approach.

This paper aims to render the appropriateness of employing the different paradigms in explicit manner. Researchers propose continuums to support the idea of paradigm interplay and experimenting. One of them is a continuum between consensus and dissensus ${ }^{27}$ where the latter allows for paradigm interplay, whereas the former allows for generating concepts using the approach on the continuum from concepts generated a' priori from theory, to emergent concepts originating from data. Howorth and other authors ${ }^{28}$ propose paradigm interplay to get more insights into the entrepreneurship as a process. Diochon et al. ${ }^{29}$ refer to work by Schultz and $\mathrm{Hatch}^{30}$ who propose to practice paradigm interplay in "transition zones" between, suggesting that Weick's work is situated in the transition zone Following this argumentation also other researchers encourage experimenting with paradigms, in social science research, talking even about "multiple" paradigm employment ${ }^{31}$.

Functionalist paradigm itself, cannot explain the inherent duality and paradoxes between social and economic in social entrepreneurship phenomenon and research. The two are usually presented as "social" versus "economic", and as "social" or "economic", so as a dichotomous choice, but there is lack of research effort serving to combine "social" and "economic". Interestingly, a lot of social entrepreneurship research is managerialist. O'Connor refers it particularly to high-profile social entrepreneurship, common in US context ${ }^{32}$. She recalls Baritz, who argued that management is not able to respond to broader social issues. Whereas market and management tools are expected to bring solutions to social issues, dating back to Taylor's principles of scientific

\footnotetext{
${ }^{25}$ K. Nicolopoulou, Social Entrepreneurship between Cross-Currents: Toward a Framework for Theoretical Restructuring of the Field, "Journal of Small Business Management" 52/4, (2014), pp. 678-702.

${ }^{26}$ O.M. Lehner, J. Kansikas, Social Entrepreneurship..., op. cit.

${ }^{27}$ M. Diochon, G. Durepos, A.R. Anderson, Understanding Opportunity..., op. cit.; M. Alvesson, S. Deetz, Critical management research, Sage, London 2000

${ }^{28}$ C. Howorth, S. Tempest, C. Coupland, Rethinking entrepreneurship methodology and definitions of the entrepreneur, "Journal of Small Business and Enterprise Development" 12/1, (2005), p. 24-40; M. Diochon, G. Durepos, A.R. Anderson, Understanding Opportunity..., op. cit.

${ }^{29}$ M. Diochon, G. Durepos, A.R. Anderson, Understanding Opportunity..., op. cit.

${ }^{30}$ M. Schultz, M.J. Hatch, Living with multiple paradigms: The case of paradigm interplay in organizational culture studies, "Academy of Management Review” 21/2, (1996), pp. 529-557.

${ }^{31}$ P. Grant, L. Perren, Small business and entrepreneurial research: meta-theories, paradigms and prejudices, "International Small Business Journal" 20/2, (2002), p. 185-211; D.A. Gioia, E. Pitre, Multiparadigm perspectives on theory building, "Academy of Management Review" 15/4, (1990), pp. 584-602; M. Diochon, G. Durepos, A.R. Anderson, Understanding Opportunity..., op. cit.

${ }^{32}$ E.S. O'Connor, Location and relocation..., op. cit.
} 
management ${ }^{33}$. This has been to date practiced through various socially responsible policies among corporations, mainly, as she emphasizes for business to redeem itself, in the face of current scandals and sins of modern capitalism, with social and environmental harms and impact on society and economy. The claimed dichotomy between the social and the economic, serves as opportunity for integrative approach, using both paradigms interpretivist and functionalist. Interpretivist lenses provide such opportunity, as they include perspective of individual, subjective experience, with their context. Therefore social phenomena can be reconsidered in its economic context, but also economic phenomenon includes societal context.

Business and management theory and practice cannot disregard issues of responsibility. In his recent paper Pfeffer emphasizes and argues for putting utmost attention to human costs, and inclusion of psychological and physical health issues in organization and management research ${ }^{34}$. He says, that it is not for the matter of economic calculus, costs and profits, but because they are important "outcomes in their own right". Social responsibility, therefore, should not be means to economic ends, but equally important focus of each organizations. The humanistic management places management and entrepreneurial processes in human -individual oriented position. Humanism should be treated as valuable improvement of economic aspect of business and enterprise. Such approaches stand in direct opposition to neoclassical economic treatment of business and organizational processes. More and more convergence needs to be seen between social entrepreneurship, CSR and sustainable entrepreneurship - in theory and practice, as they all are manifestations of humanism and societal approach in business and management ${ }^{35}$.

\section{CONCLUSIONS}

The complexity of social entrepreneurship phenomenon requires a broader approach to the people, enterprise, environment and all constituting elements. First of all, it should not be treated as a field or domain separate from entrepreneurship research, but constitute its subfield. Considering these, we claim to approach it as societal entrepreneurship. The complexity, generated by the context, and the processual nature of this phenomenon necessitates to move away from functionalist paradigm approach towards interpretivist. Also, as social entrepreneurship is a phenomenon relevant and approached by academics from different disciplines, we recognize the need for broadening the extent of social aim, as a distinguishing feature of social enterprise - in theory and practice. This is not narrowly defined social problem of particular social groups, but it covers any aspects of social changes, resulting from struggles and conflicts, in efforts for empowerment of a variety of social groups and their problems. As a result, more entrepreneurship research could be potentially done via employment of radical change approach. The main argument for considering and researching social entrepreneurship as a phenomenon on the intersection between the discussed paradigms, is its highly contextual nature, complexity

${ }^{33}$ For valuable review of management problems see more: M. Szarucki, Evolution of managerial problems from the perspective of management science, "Business: Theory and Practice" 16/4, (2015), pp. 362-372.

34 J. Pfeffer, Why the Assholes are Winning: Money Trumps All, "Journal of Management Studies" 53(4), (2016), pp. 663-669.

${ }^{35}$ M.A. Pirson, P.R. Lawrence, Humanism in Business: Towards a Paradigm Shift?, "Journal of Business Ethics” 93(4), (2010), p. 553-565; K. Nicolopoulou, Social Entrepreneurship ..., op. cit. 
of the subject and process as well as recognition of a social problem in much broader terms.

\section{REFERENCES}

[1] Alvesson M., Deetz D., Critical management research, Sage, London 2000.

[2] Anderson A.R., Dodd S.D., Jack S.L., Network practices and entrepreneurial growth, "Scandinavian Journal of Management" 26/2, (2010), p. 121-133.

[3] Burrell G., Morgan G., Sociological paradigms and Organizational Analysis, Heinemann, London 1979.

[4] Ciepielewska-Kowalik A., Pieliński B., Starnawska M., Szymańska A., Social enterprise in Poland: institutional and historical context, "ICSEM Working Papers" 11, (2015) The International Comparative Social Enterprise Models (ICSEM) Project: Liege.

[5] Defourny J., Nyssens M., The EMES approach of social enterprise in a comparative perspective, "Working Paper" nr 12/03, (2013), EMES European Research Network.

[6] Diochon M., Durepos G., Anderson A.R., Understanding Opportunity in Social Entrepreneurship as Paradigm Interplay, [in:] Social and Sustainable Entrepreneurship. Advances in Entrepreneurship, Firm Emergence and Growth 13, eds. G.T. Lumpkin, J.A. Katz, Emerald Group Publishing Limited, Published Online 2011, p. 73-110.

[7] Doherty B., Haugh H., Lyon F., Social enterprises as hybrid organizations: a review and research agenda, "International Journal of Management Reviews" 16, (2014), p. 417-436.

[8] Gioia D.A., Pitre E., Multiparadigm perspectives on theory building, "Academy of Management Review" 15/4, (1990), p. 584-602.

[9] Grant P., Perren L., Small business and entrepreneurial research: meta-theories, paradigms and prejudices, "International Small Business Journal" 20/2, (2002), p. 185-211.

[10] Howorth C., Tempest S., Coupland C., Rethinking entrepreneurship methodology and definitions of the entrepreneur, "Journal of Small Business and Enterprise Development" 12/1, (2005), p. 24-40.

[11] Kaufman H., Time, Chance, and Organizations, Chatham House, Chatham, NJ 1985.

[12] Lee M., Battilana J., Wang T., Building and infrastructure for empirical research on social enterprise: challenges and opportunities, [in:] Social Entrepreneurship and Research Methods, ed. J. Short, Emerald Group Publishing Limited, Published Online 2014, p. 241-264.

[13] Lehner O.M., Kansikas J., Social Entrepreneurship Research across Disciplines: Paradigmatic and Methodological Considerations, 3rd EMES Research Conference, Social Innovation through Social Entrepreneurship in Civil Society, 4-7 July 2011, Roskilde University, Denmark.

[14] Nicholls A., The Legitimacy of Social Entrepreneurship: Reflexive Isomorphism in a Pre-Paradigmatic Field, "Entrepreneurship Theory and Practice" 34/4, (2010), p. 611-633. 
[15] Nicolopoulou K., Social Entrepreneurship between Cross-Currents: Toward a Framework for Theoretical Restructuring of the Field, "Journal of Small Business Management" 52/4, (2014), p. 678-702.

[16] O'Connor E.S., Location and relocation, visions and revisions: opportunities for social entrepreneurship, [in:] Entrepreneurship as Social Change, eds. C. Steyaert, D. Hjorth, Edward Elgar, Cheltenham UK and Northampton MA USA 2006, p. 79-96.

[17] Piecuch T., Charakterystyka przedsiębiorców społecznych - przegląd literatury, „Ekonomia Społeczna” 2, (2014), p. 58-68.

[18] Pirson M.A., Lawrence P.R., Humanism in Business: Towards a Paradigm Shift?, "Journal of Business Ethics" 93(4), (2010), p. 553-565.

[19] Pfeffer J., Why the Assholes are Winning: Money Trumps All, "Journal of Management Studies" 53(4), (2016), p. 663-669.

[20] Poselski projekt ustawy o przedsiębiorstwie społecznym $i$ wspieraniu podmiotów ekonomii społecznej. 2015. http://orka.sejm.gov.pl/Druki7ka.nsf/0/B349885CF7ED 5077C1257E690042C6D9/\%24File/3521-ustawa.docx.

[21] Schultz M., Hatch M.J., Living with multiple paradigms: The case of paradigm interplay in organizational culture studies, "Academy of Management Review" 21/2, (1996), p. 529-557.

[22] Starnawska M., Social entrepreneurship research - challenges, explanations and suggestions for the field development, "Problemy Zarządzania" 3/61, (2016), p. 13-31.

[23] Swedberg R., Social entrepreneurship: the view of the young Schumpeter [in:] Entrepreneurship as Social Change, eds. C. Steyaert, D. Hjorth, Edward Elgar, Cheltenham UK and Northampton MA USA 2006, p. 21-34.

[24] Szarucki M., Evolution of managerial problems from the perspective of management science, "Business: Theory and Practice" 16/4, (2015), p. 362-372.

\section{PRZEDSIĘBIORCZOŚĆ SPOŁECZNA I ŚCIEŻKI ROZWOJU OBSZARU BADAWCZEGO NA SKRZYŻOWANIU PARADYGMATÓW BADAWCZYCH}

Celem niniejszego artykułu jest identyfikacja kluczowych uwarunkowań, mogących stanowić argumenty za stosowaniem różnych paradygmatów badawczych w badaniu zjawiska przedsiębiorczości społecznej według klasyfikacji Burrella i Morgana. Autorka postuluje podejście, sugerujące, że wykorzystywane paradygmaty badawcze nie wykluczają się wzajemnie. Natomiast w przestrzeni wzajemnych intersekcji mogą stanowić użyteczne podejście w wyjaśnianiu, opisywaniu i eksplorowaniu tego zjawiska. Przedsiębiorczość społeczna jako obszar badań znajduje się we wczesnej fazie rozwoju, co sprzyja wolności w dyskusji nad wyborem paradygmatu badawczego. Traktowanie zjawiska przedsiębiorczości społecznej jako podobszaru przedsiębiorczości, pozwala ujmować ją w kategoriach szerszych niż tylko tych które są związane z typowym jej celem, jakim jest rozwiązywanie problemów społecznych, socjalnych. Autorka identyfikuje cechy charakteryzujące przedsiębiorczość społeczną sensu largo i wykorzystuje je jako argumenty do większej swobody $\mathrm{w}$ doborze i równoczesnym stosowaniu (dotychczas traktowanych jako wzajemnie wykluczające się) paradygmatów badawczych. W początkowej części artykułu autorka przedstawia pojęcie przedsiębiorczości społecznej w badaniach i stan rozwoju tychże. W dalszej części wyodrębnia i identyfikuje ważne elementy społecznego wymiaru przedsiębiorczości spo- 
łecznej, zwracając uwagę na niematerialne i trudno uchwytne elementy procesu przedsiębiorczego, tygla interakcji społecznych, kontekstualności i procesualności tego zjawiska. Dalej następujący przegląd paradygmatów badawczych pozwala na przeprowadzenie dyskusji nad możliwościami poszerzenia wiedzy na temat obszaru przedsiębiorczości społecznej przy wykorzystaniu różnych paradygmatów.

Słowa kluczowe: Przedsiębiorczość społeczna, przedsiębiorstwo społeczne, metodologia, paradygmat badawczy, teoria instytucjonalna.

DOI:10.7862/rz.2016.hss.74

Przestano do redakcji: wrzesień $2016 r$.

Przyjęto do druku: styczeń 2017 r. 